\title{
Financial Services in the VAT System in the European Union and Croatia
}

Ivana Dražić Lutilsky, Sanja Broz Tominac, Martina Dragija *

Abstract:

This paper presents differences in the VAT treatment of financial services. We investigated the treatment of financial services in the VAT system in EU countries as well as in Croatia, in order to reveal differences and improvement possibilities. The results show that there is a need for significant improvement in the VAT system, especially in Croatia. Furthermore, European Union countries have applied tax regulations since 1977. The research on the VAT treatment of financial services indicates that there is unequal application of tax exemptions and adverse tax competition in EU countries. Nevertheless, Croatia is still adjusting its legislation (the tax treatment of financial services) with EU provisions. Our paper thus provides a comparative analysis of the treatment of financial services in the VAT system in EU and Croatia that could be useful for the new consideration of the financial services position in the VAT system in Croatia.

Key words: financial service, VAT, tax exemption, European Union, Croatia

JEL: G20, H29

DOI: $10.2478 / v 10033-012-0012-8$

\section{Introduction}

The Value Added Tax (VAT) is the most abundant tax form in Croatia. Since the VAT was implemented in the Croatian tax system, financial services sector has had a specific tax position. Financial intermediation formed 5,4 $\%$ of the gross domestic product of Croatia in 2007, with an expressed tendency for growth (CBS, 2010). The aim of this paper is to research the position of financial services in the VAT system in Croatia and the European Union. In the European Union there is debate about the reform and modernization of the existing tax treatment of financial services, because of legal and economic distortions in the financial industry and its users. At the same time big changes in the Croatian Law on VAT came into force on 1st January 2010, and caused significant changes in VAT impact on the financial industry. Those changes represent a big challenge for all financial services providers in Croatia. Financial services are the economic services provided by the finance industry, which encompasses a broad range of organizations that manage money, including credit unions, banks, credit card companies, insurance companies, consumer finance companies, stock brokerages, investment funds and some government sponsored enterprises.

\section{* Ivana Dražić Lutilsky}

Faculty of Economics and Business Zagreb, University of Zagreb, Croatia,

E-mail: idrazic@efzg.hr

\section{Sanja Broz Tominac}

Faculty of Economics and Business Zagreb, University of Zagreb, Croatia,

E-mail:sbroz@efzg.hr

\section{Martina Dragija}

Faculty of Economics and Business Zagreb, University of Zagreb, Croatia

E-mail: mdragija@efzg.hr 


\section{Financial Services and VAT in the European} Union

The category of tax exemptions includes, among others, financial services. That fact is an issue of long debate of economic theory and tax practices. While the reasons for other exemptions in the VAT system are acceptable for the public sector, exemptions for financial services are not. Difficulty in determining the tax base is not a sufficient argument for tax exemptions. The critics' opinion is that financial services must be taxable in order to respect the principle of VAT neutrality. Economic distortion would be avoided in this way. Despite those reasons, in almost every country, financial services are not taxable. The main reasons for this are the following (Šimović et al, 2006, p.174):

- Inability to determine added value on the transaction level, i.e. difficulties in determining the tax base, and

- Fear of overflow of tax burden on interest rate levels.

\subsection{Obsolescence of Existing Legislation and \\ Discrepancy in Application in EU Countries}

Since the 6th Directive was adopted in 1977, financial services in EU countries are excluded from VAT taxation. This means that the VAT is not calculated on the delivery of financial services, and the deliverer cannot calculate a VAT receivable deduction for inputs that are used in financial service delivery. This exemption was prescribed by article 13.B. of the same Directive. In the text there is an option for financial service taxation and each EU member state is allowed to prescribe its own limitations

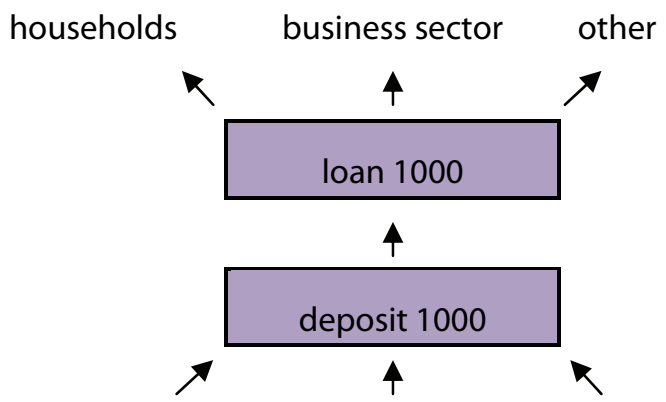

households business sector

other

for that option (Sixth Council Directive 77/388/EEC, 1977). Despite this, every member state chose not to tax financial services for the abovementioned reasons.

Nonetheless, a service fee is often intertwined with other components of financial transactions and its amount is very hard to identify at the level of individual transactions.

The figure below illustrates the cash flow components by deposit-credit bank transactions.

It is very understandable why tax authorities are not disposed to tax these transactions, as today there is no efficient mechanism that can separate the value of the agential activity of the financial agent, which should be the object of taxation.

The volume of financial services is the same also in the relatively new Directive 2006/112/EC that was adopted on 1st January 2007. The Directive is especially interesting given the big changes that have occurred, as well as the financial industry's rapid development in the last thirty years. In this sense, in article 135 of the Directive 2006/112/EC the following financial services exemptions are prescribed (Council Directive 2006/112/EC):

- Approval and contracting of loans, and credit management;

- Contracting or any kind of credit guarantee trade or other securities for money, and credit guarantee management;

- Transactions, including intermediation in connection with deposit and current accounts, payments, assignments, debts, checks and other transferable instruments, but excluding collection;

- Transactions, including intermediation in connection with currency, banknotes and coins that are used as a legal payment instrument, with the

"min received interest

min paid interest
100

Figure 1: The value of bank services to deponents and credit users

Source: (Ernst \& Young, 2009, 12) 
Financial Services in the VAT System in the European Union and Croatia

\begin{tabular}{|c|c|c|}
\hline Country & $\begin{array}{c}\text { VAT calculation on factoring } \\
\text { service/commission }\end{array}$ & $\begin{array}{l}\text { VAT calculation on } \\
\text { interest/discount }\end{array}$ \\
\hline Austria & YES & NO \\
\hline Belgium & YES & YES \\
\hline Cyprus & YES & NO \\
\hline Czech Republic & YES & NO \\
\hline Denmark & YES & NO \\
\hline Estonia & YES & NO \\
\hline Finland & NO & NO \\
\hline France & YES & YES \\
\hline Greece & YES & YES \\
\hline Ireland & YES & YES \\
\hline Italy & NO & NO \\
\hline Lithuania & YES & YES \\
\hline Latvia & YES & NO \\
\hline Hungary & NO & NO \\
\hline Netherlands & YES & NO \\
\hline Germany & YES & YES \\
\hline Poland & YES & YES \\
\hline Portugal & NO & NO \\
\hline Romania & YES & YES \\
\hline Slovakia & YES & NO \\
\hline Slovenia & YES & YES \\
\hline Spain & YES & NO \\
\hline Sweden & YES & YES \\
\hline United Kingdom & YES & $\mathrm{NO}$ \\
\hline
\end{tabular}

Table 1: VAT calculation on factoring service sin EU member countries Source: (International Factors Group, 2008)

exemption of collection items;

Member states and financial institutions have the common problem of interpreting the definition of tax exemptions from article 135 of Directive 2006/112/EC. The abovementioned brought the implementation of various solutions into national legislations, which led to the inconsistent application of the VAT on the common market. The consequences have been different conditions for economic subjects in filing the VAT, i.e. interpretations vary by member state. Many international financial institutions when expanding their business on new markets are forced to negotiate with every member state about exemption interpretations. This represents significant costs and barriers for investments. Table 1 provides an overview of the unequal application of the VAT in EU member countries.

For tax administration there are risks of lost tax revenues, and for legal entities legal insecurity precludes long-term planning and causes segregation of significant items for the taxation problem's resolution.

\subsection{Deduction and Distribution of VAT Receivables}

By the Directive 2006/112/EC general conditions are prescribed that must be satisfied cumulatively in order to deduct VAT receivables from an incoming invoice (Council Directive 2006/112/EC):

- That taxpayer has an invoice for the delivered goods or services that has been issued according to the Directive;

- That there are no expenses for which there is no possibility for tax deduction such as expenses for luxury, entertainment and pleasure; and

- That obtained goods and services are used for taxable transactions purposes. 


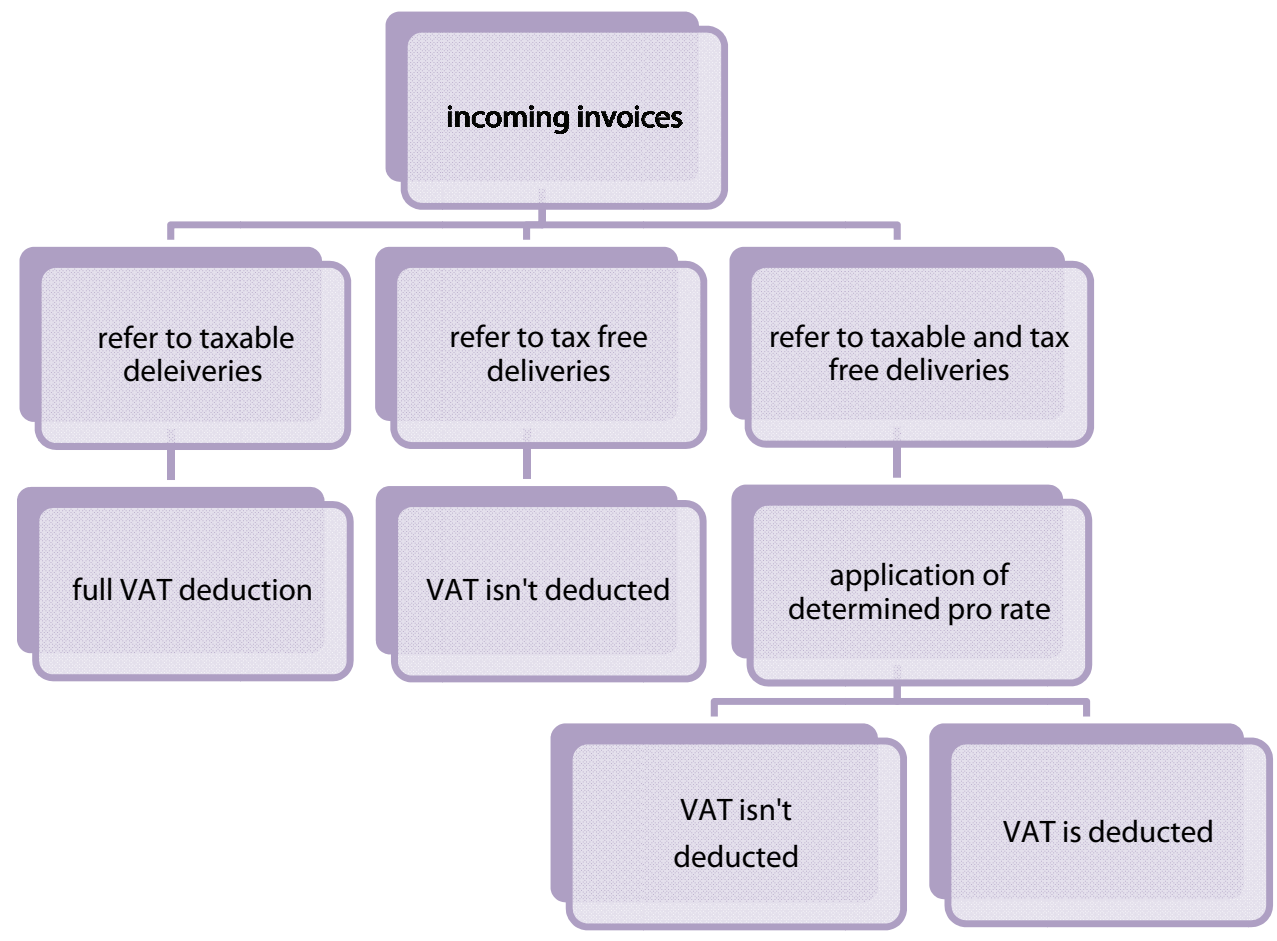

Figure 2: VAT receivables deduction by financial institutions

Source: authors

Financial institutions with headquarters in the European Union do not have the possibility to deduct VAT receivables on financial service deliveries in the European Union, but have the possibility for financial service deliveries outside the European Union.

Essentially, on the basis of relations between taxable and nontaxable deliveries of tax payers, the percentage of VAT receivable deduction for income invoices (that refer to taxable and exemption deliveries) should be calculated. There is a calculation of VAT receivable deduction precisely defined as the following fraction on an annual level (Council Directive 2006/112/EC):

\section{Total amount (without VAT) of deliveries for which there is a right to VAT deduction}

Total amount of deliveries included in numerator and deliveries for which there is no possibility for VAT deduction

From the calculation of the part of the VAT receivables that can be deducted, some value significant items that could disturb the actual condition, i.e. bring VAT receivables deductions that do not arise from actual taxable business from regular activities. Amounts that are excluded from calculation include (Council Directive 2006/112/EC):
- The amount of deliveries of capital goods that are used from taxpayers in business,

- The amount of occasional deliveries of real estate, and

- The amount of occasional financial transactions from article 135 of the Directive.

The tax that has to be deducted in the current year is calculated on the basis of transactions from the previous year, and that deduction is temporary and has to be adjusted in the final VAT calculation. According to the abovementioned, tax payers can deduct the entire amount of VAT receivables in the tax period that can be directly assigned to taxable deliveries, as well as the amount of VAT receivables calculated as a product of the VAT deduction rate and the total amount of VAT for invoices that can be assigned to taxable and tax free deliveries. The VAT that is included in incoming invoices that are connected to tax free deliveries of financial institutions cannot be deducted by the tax payer. Those rules are concisely shown in Figure 2 .

In practice, incoming invoice analysis is a very demanding process. For financial institutions the process of analysis and incoming invoice registration consists of several phases. The key factor in the process is the phase of identification and incoming invoice classification in 
one of the three abovementioned categories. Often it is very difficult to resolve to which outgoing delivery an incoming invoice can be assigned. The decision of the tax payer about the way incoming invoices are classified leave insecurity and possible adjudication for tax inspectors. As in the financial industry there are large systems with enormous amounts of data that demand the automatization of business processes, the legal insecurity of this field generates high administrative costs and represents a considerable criticism to the existing financial services position in the VAT system.

\subsection{Economic Effects of the Existing Tax Status of Financial Services}

The economic effects of the existing tax status of financial services arise first from the fact that financial institutions which deliver services and which are according to article 135 of the Directive VAT free cannot deduct VAT receivables included in incoming invoices, and that are connected to those tax free deliveries. In this way, the tax included in incoming invoices represents a cost component of financial institutions, and increase the prices of their services. A non-deductable tax is called a hidden VAT and causes the cascade effect of VAT (European Commission, 2006, p.6). An example representing the cascade effect from financial services in practice is presented here:
VAT results in either decreased profitability or higher prices that have a negative impact on their business. Despite the fact that the non-deductable tax is included in the price of financial services for a natural person, the geniality of exemption is recognised in the fact that there is no VAT taxation (the costs of labour and profit) for banks. It can be concluded that the exemption of financial services has an impact on the higher prices of those services for business subjects and the lower prices of the same services for final users. Due to the fact that one of the basic characteristics of VAT is its regression, it can be concluded that the financial services exemption has a corrective effect (European Commission, 2006, p.20).

It is clear that the VAT can be a deciding factor in decision-making for financial institutions regarding isolating certain activities from banks. The nondeductable VAT, either partly or on the whole, nullifies all of the positive effects of isolating these activities. In fact, in certain circumstances it is possible that the initial intention of cost reduction leads to cost increases.

If we assume that the only goal of isolating activities is cost reduction, it is clear that such savings must cover the non-deductable VAT. The higher the VAT rate, the higher the amount of savings needed.

As the main goal of isolating activities is to achieve savings, the tax exemption of financial services causes the adverse effect. That is, it increases the costs of financial

Accounts payables $100+20($ VAT) $\rightarrow$ Bank $200 \rightarrow$ Client-entrepreneur 400+80 VAT (480)

$100+20+80$ (profit) $\quad 100+20+80+100$ (own cost) +100 (profit) +80 (VAT)

Table 2: Example of cascade effect by financial services

Source: (European Commission, 2006, 6)

The result of tax exemption of financial services is declared in the fact that the tax included in the incoming invoice represents the cost to the bank and is a part of the financial service price. That hidden VAT represents the cost component of the client and is a part of the product or service price. It is evident that the tax examination from the first example causes economic distortions in the cascade effect of VAT, which increases the prices of the financial industry and also the service of other users of financial services. For financial service users tax exemptions cause higher incoming costs, which have a negative impact on the prices of their products and services, i.e. their competitiveness. For financial institutions tax exemptions or the cascade effect of the institutions. This is the reason why providers of financial services often resort to vertical activity integrations (selfsupply) (European Commission, 2007, p.20). Financial institutions become inclined to ensure deliveries of certain taxable services inside the company (for example IT services, data processing) rather than use services from external suppliers that generate the problem of a nondeductable tax. Because of the tax benefit of internalization, financial institutions are stimulated to choose sub-optimal business models which have negative impacts on the sector competitiveness of financial services in the European Union (European Commission, 2007, p.20). 
This also does not lead to the positive development of competition in the field of financial services. In fact, smaller financial institutions do not have the financial capacities to ensure all of the activities can be done internally and are forced to use services from suppliers. As mentioned in the model weighted with non-deductable VAT, this generates additional significant difficulties in market competition with bigger and financial forceful financial institutions. It is important to mention that in the context of economic distortion measurement, differences in VAT rates in the member states have a significant role in EU member states. This results in the preferential status of financial institutions in countries with lower standard VAT rates (PricewaterhouseCoopers, 2006, p.13). As those differences are significant there is the problem of the disloyal competition of financial services providers in the EU.

The following table shows the impact of different tax rates in two EU member states on financial institution competitiveness.

\begin{tabular}{|l|c|c|}
\hline \multicolumn{1}{|c|}{ Incoming expenses } & \multicolumn{2}{c|}{ Tax free deliveries } \\
\hline $\begin{array}{l}\text { Total incoming expenses } \\
\text { (without VAT) }\end{array}$ & 10.000 & Sweden \\
\hline Total labour costs & 1.000 & 1.0000 \\
\hline Total costs of taxable inputs & 9.000 & 9.000 \\
\hline VAT rate & $15 \%$ & $25 \%$ \\
\hline VAT by incoming costs & 1.350 & 2.250 \\
\hline Total incoming costs & 11.350 & 12.250 \\
\hline Case 1. VAT included in & Cyprus & Sweden \\
\hline Total revenues (without VAT) & 13.350 & 14.250 \\
\hline Income before taxes & 2.000 & 2.000 \\
\hline Case 2. VAT included in \\
margin & Cyprus & Sweden \\
\hline Total revenues (without VAT) & 12.000 & 12.000 \\
\hline Income before taxes & 650 & $(250)$ \\
\hline
\end{tabular}

Table 3: The impact of different tax rates in EU members on financial institution competitiveness

Source: authors

By international transactions, this impact of VAT rates could bring significant comparative advantages to financial services providers from countries with lower tax rates (PriceWaterhouseCoopers, 2006, str.13). Of course, that is just an example that does not take into account other factors which have impacts on the competitiveness of financial institutions in European Union, but is more than sufficient to confirm the consequences of nonharmonized tax rates in EU member countries. Except differences in tax rates, there is also the impact of differences in national legislations and the possibility that one country provides for financial institutions in optimizing its status. Although difficulties in connection with the VAT do not have the most dominant impact on their business decisions, it seems that the role of taxmitigating circumstances is not negligible. That is visible from the year-long financial institution struggle in order to convince the national authorities and European Commission of the necessity of solving VAT problems for the financial services sector. The reaction of member countries goes in two directions (European Commission, 2006, p.8):

- Exclusively focusing on tax collection, where the member country gives priority to budgetary concerns and estimates a low risk of financial sector mobility; or

- Prevailing macroeconomic interest in attracting or maintaining key industries that are the most significant for certain member states, and where factor costs are high and/or risk of industry mobility exceeds budget interests.

According to the research of PriceWaterhouseCoppers from 2006, financial institutions in the European Union consider the differences in tax treatment of financial services to represent the source of competitive advantages for financial institutions that have headquarters in countries with optimal tax regimes for financial services. Those countries are the United Kingdom, Luxembourg, Ireland and Belgium (PriceWaterhouseCoopers, 2006, p.17). Despite the long harmonization process of the VAT system in the European Union, significant differences have arisen in the first way from possibilities that are allowed by the Directives to member states, namely from the interpretation and implementation of the Directives and the solutions that are applied in practice.

Concerning the possibilities for tax exemption by cost distribution, the difference between what is legally allowed and what is practically achievable is especially interesting. This situation refers to the part of new member countries that have introduced provisions into national legislations but without directions. Legal insecurity due to numerous obscurities in this field is still present. 
On the global level the VAT regime in the European Union has a significant impact on the international competitiveness of the financial institutions of the European Union. The absence of taxes or favorable tax treatment of financial services undoubtedly can provide significant price advantages for financial institutions with headquarters outside the European Union. Due to the existing treatment of financial services, banks with headquarters in the European Union are motivated to do their business outside the European Union. It is common practice for the largest financial institutions of the European Union to establish subsidiaries in countries outside the European Union.

\subsection{Reform and Modernization of the Financial Services Tax System}

When in 1977 by the Sixth Directive tax exemption for financial services was presented, it was considered a transitional solution. That belief prevailed because of the disadvantages of tax exemption (without VAT receivables deduction), which is not appropriate for proclaimed VAT neutrality (European Commission, 2007, p.7). Nondeductable VAT and the resulting cascade effect with all of its economic distortions was considered unacceptable. The European Commission aimed for the development of a full taxation model of financial services in order to remove the distortions caused by tax exemptions. But despite its wishes, just twenty years ago it started to audit the tax treatment of financial services. As the only method that has shown potential as a starting point in the direction of the abovementioned auditing, the possibility of full taxation of financial services was proposed through a cash-flow mechanism (De la Feria et al, 2009).

This would mean that transactions by which the fee is hidden in the margins of all cash inflows to banks are treated as taxable deliveries that are taxed by a general tax rate, and that all cash flow outflows are treated as inputs, with the right to VAT deduction. However, this method showed certain disadvantages. This method would involve calculating and paying large amounts of taxes and VAT receivable deductions in different periods which would not be good for the liquidity of business subjects and national budgets (European Commission, 1996, p.95). It is unacceptable that business subjects have to calculate and pay VAT, which makes its need for financing additionally weighted. This could be an especially difficult burden for smaller financial institutions with smaller financial capacities. Serious problems could arise in the case of changes to the tax legislation.

In order to remove these disadvantages of the cash flow method, the tax experts Satya Poddar and Morley English proposed in 1997 the modification of the original cash flow method by using special accounts for tax calculation (tax calculation account method), (De la Feria et al, 2009, p.26). The essence of the TCA method is in fact that the transfer of capital funds from banks to users, as well as capital refunds, are not taxable.

The taxable issue is the part of the calculated interest rate which represents the implicit fee for the service, while the so-called clean or normal interest as a part of total interest does not fall under taxation (European Commission, Taxation and Customs Union, 1996, p.105). The tax authorities should determine the level of the clean interest rate, and for that purpose there is an interest rate on government bonds or interest rate by which the government is indebted. By defining the clean interest rate, the tax authorities directly determine which part of the bank fee represents the fee for financial services which is taxable. Also, by the TCA method, the risk of tax legislation change is decreased. There are some disadvantages in connection with the complicated calculation of the tax obligation with respect to the cash flow method. Defining a clean interest rate is also a problem, because any interest rate that is too high leads to the enhanced taxation of savings and decreased credit taxation, with a distortion effect on the financial activities of economic subjects (European Commission, Taxation and Customs Union, 1996, p.105). It was proved that the TCA method can be applied to all financial services, including the most complex, such as derivatives, and that it does not cause a cascade tax effect. Despite the abovementioned conclusions, the proposal was reflected in the Fiscalis seminar in 2004. The concept of full taxation of financial services was abandoned by the Commission (European Commission, 2007, p.9). It seems that the administrative complexity of this method was the insuperable barrier to the eventual application of financial services taxation. It should be mentioned that no country outside the European Union had a simple and appropriate method for financial services taxation. All of the leading states in the world (except the United States) apply value added tax and have a common question regarding financial services taxation. Usually, countries have exemptions on most financial services deliveries whilst implementing certain mechanisms for the "struggle," with the most significant disadvantages of 
that exemption, especially in the field of negative impacts on international competitiveness. In spite of the adjudication issue, there is broad professional consensus that the exemption of financial services is the only realizable solution (European Commission, 2007, p.9).

\section{Financial Services and the VAT in Croatia}

In almost all of the countries which apply the VAT, including EU member countries, financial services are usually exempted from VAT taxation. The Croatian system of VAT applies tax exemptions on financial services deliveries, but in a different way. The specific tax treatment of financial services in the Croatian system of VAT lasted from 1 January 1998 to 31 December 2009.

\subsection{Status of Financial Services in the VAT System}

Before $1^{\text {st }}$ January 2010

The Croatian approach to the tax exemption of financial services was presented in June 1995 when Croatian parliament passed the Law on VAT, by which the aforementioned tax was introduced into the Croatian tax system. Bank services, savings banks services, insurance and reinsurance companies' services were exempt from the VAT. That exemption was extended to the Croatian national bank and the exemption is conditioned just for those institutions whose business is arranged by special regulation (Official Gazette, 1996, 60/96; Official Gazette, 1995, 47/95). If financial services are made by entrepreneurs that are not a bank, savings bank or insurance and reinsurance company, they are taxable. The essence of institutional exemption is the provision of financial services and not the character of the financial service. The consequence of these regulations is that the identical service is sometimes taxed and sometimes not. For example, the advisory service that was provided by a "regular" non-banking company is taxable; when it was provided by a bank, it is exempt. In the next table the impact of institutional exemptions on market competition is shown. This example shows the impact of VAT receivables as the target profit level is identical for both suppliers (the VAT rate was increased in Croatia from $23 \%$ to $25 \%$ on 1 st March 2012).

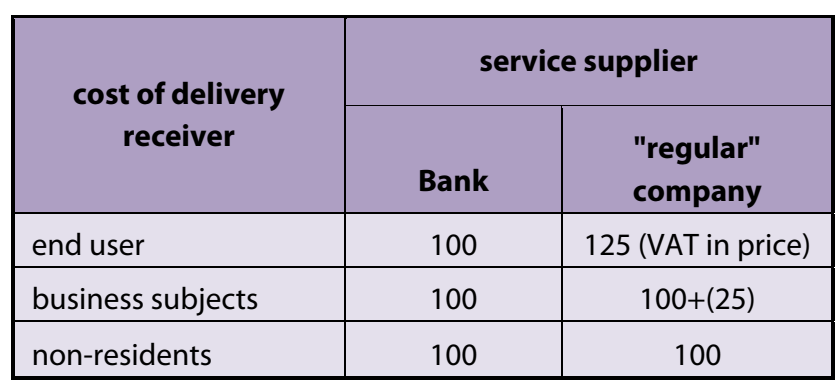

Table 4: The impact of institutional exemption on market competition and "regular" business subjects

Source: authors

As one can see, the bank achieves a significant competitive advantage ahead of the regular company. The end user cannot deduct the tax which increases the price of the received service by $23 \%$ in comparison with the identical delivery from the bank. In order to be competitive with institutionally exempted companies, other companies can decide to decrease their own profitability for that tax burden. In both ways it is evident that institutional exemption puts financial institutions in a preferential tax situation.

When it is about deliveries to business subjects, the VAT is neutral for entrepreneurs and delivery receivers due to fact that they can deduct VAT receivables. In spite of this, there is an additional financial burden for entrepreneurs that has impacts on liquidity. This is the reason why entrepreneurs are liable to identical bank deliveries. However, in this situation the issue of VAT receivables that can change the affinity of a business subject-service receiver should be mentioned.

we consider deliveries to non-residents it is evident that the bank and regular company as service suppliers are in the same situation. The delivery from the bank is not a taxable issue, no matter who is on the side of the service receiver. On the other hand, the service delivery of a regular company to non-residents in most cases is not taxable. That means that the abovementioned service will be taxed in the country of the service receiver, which is a foreign business subject - the receiver has to apply the reverse charge mechanism of taxation and calculate the VAT on the received service, no matter by whom the service was provided.

All of the abovementioned can be applied in the case of interest rate, although with some additional specifications. In fact, the interest as a fee for financing was taxable till 31 December 2009. The tax base consisted of interest and if it was lower than $6 \%$, the tax basis was the interest of $6 \%$ annually. From January 2006 that percentage was decreased to $4 \%$. 
Interest taxation depends on the tax status of the person that charges the interest, i.e., if interest is charged by the tax payer, it will be taxable, and vice versa. The exception to this rule exists in the case of financial funds investments in banks and savings banks for tax payers. In this case the interest is not taxable, and regards a logical exception for interest on the deposits of tax payers.

As a consequence of the prescribed institutional exemption, banks and savings banks have not been considered a permanent tax payer and were not recorded in the register of tax payers, meaning that the abovementioned institutions did not have the possibility to deduct VAT receivables.

There are significant distortions caused by institutional exemptions in practice. One of the key principles of the VAT is that the same service has to be taxed in the same way. Based upon the abovement problems, the neutrality of VAT is degraded.

\subsection{Status of Financial Services in the VAT System after $1^{\text {st }}$ January 2010}

Possibly the most important novelty that arose from the new Law on VAT regards the cancellation of institutional exemptions of financial services. In accordance with Directive 2006/112/EC functional exemptions of financial services were introduced into the Croatian tax system. That means that for tax exemption the character of the financial service is important.

The following are exempt from VAT payment (Official Gazette, 2009, 87/09):

- loan approval,

- contracting of credit guarantees,

- transactions in connection with current accounts, savings accounts, shares, etc.,

- investment fund management.

\subsection{Problems in Implementation of the VAT on Financial Services and Possible Solutions towards Greater Legal Safety and Efficiency For Entrepreneurs}

Due to institutional exemption there was no need for considering financial services. The lack of clarity of the regulations and the absence of practical experience represented additional burdens to financial institutions and other providers of financial services by implementing the functional exemption of financial services. Two main problems in the process should be isolated:
1. determining the correct tax status of financial services, and

2. the question of VAT deduction.

When we talk about possible solutions in order to improve the existing position of financial services in Croatia, the key role and responsibility in this process should be transferred to the tax authorities. Without a changed approach from the tax authorities, neither improvement is possible. The approach should include a more active role by tax authorities in finding solutions to help business subjects.

As possible solutions in order to ensure a higher level of legal security and efficiency for suppliers of financial services but also for tax administration the following measures were proposed (Šalata, 2011, p.155):

- Adopting new regulation or procedures that will define tax exemptions for financial services in detail,

- Allow abjuration of the right to deduct VAT receivables without legal penalty,

- Enable the right to deduct VAT receivables for financial services provided in foreign countries,

- Introduce arrangements for cost distribution,

- Extend the option for taxation, and

- Enable the creation of VAT classes.

The creation of one collective document that will define the application of tax exemptions is a logical solution towards the increased legal security of financial services providers. Such a document would significantly contribute to cost reduction. All parties should be involved in its creation, and they should investigate the economic essence of financial transactions and analyze foreign practices and solutions.

Providers of financial services should be allowed to give up the right to VAT receivables deduction. Smaller financial institutions are affected by the current solution because they are forced on additional administrative costs which exceed the financial effects of VAT receivables deduction. The expected positive effects on government revenues should encourage tax authorities to support this measure.

In order for there to be an equal position for Croatian providers of financial services with European competitors there should be the ability for Croatian subjects to deduct VAT receivables for financial services that are provided in foreign countries. Through this, the competitiveness of Croatian providers on the global financial market would 
be increased. The expected negative impact on the national budget would be replaced by increased engagement of Croatian subjects in foreign countries.

The current regulations about taxation possibilities are very tight and have too many restrictions. Introducing taxation possibilities on the basis of certain transactions will help providers to optimize their right for VAT receivables deduction and the cascade tax effect would be minimized. The main positive effect would be an increased base for direct taxes calculation.

All of the abovementioned measures towards increased legal security and efficiency for entrepreneurs are not exclusively geared toward the Croatian financial industry. Most of the measures have already been incorporated into the national tax systems of many EU member countries, and are foreseen as a part of the tax treatment of financial services reform. By adopting these measures Croatia would enter the group of countries with a stimulatory legal framework for the provision of financial services, and one that manages and develops actively its most abundant tax source.

\section{Conclusions}

Regulations on the taxation of financial services in the European Union date from 1977. Aside from the fact that the rules are obsolete and cannot follow the development of the financial industry, their problems include numerous obscurities. These resulted in the unequal application of exemptions and damaging tax competitiveness in EU member countries. Distortion of VAT neutrality through the application of the tax exemptions of financial services brought numerous negative economic effects. In 2007 Directive COM/2007/47 was issued which introduced measures for reaching goals and explaining tax exemptions. Despite certain critics, the proposed measures represent an improvement with respect to the existing solutions.

With regard to Croatia, general consideration of the VAT system regarding financial services shows that it is unsatisfactory. An initially good VAT system has continuously deteriorated, instead of being upgraded with solutions that would follow the practical needs of tax payers and simplify its application.

Since the VAT was introduced in the Croatian tax system the financial services sector has had special tax treatment. Despite all of the negative characteristics of the institutional exemptions of financial services, after twelve years of application the exemption of financial services under a functional principle was introduced.

It is practically inexplicable why at a point when the European Union is proposing new regulations towards the modernization of existing financial services tax treatment, Croatia has adjusted its legislation with provisions from 1977. Instead, Croatia could learn from foreign experiences and past mistakes.

In the forthcoming period, and especially when Croatia enters the European Union, it is expected that further development of the financial industry and an increase in its portion of the Croatian GDP will occur. Within its region, the Croatian financial sector is considered the most developed. In today's technologically developed and highly globalised world, the financial industry is extraordinary mobile, and under the pressure of cost efficiency it demands continuously the most optimal destinations for its activities. $[$.

\section{References}

Croatian Bureau of Statistics, 2010. Statistički ljetopis Republike Hrvatske 2010., Zagreb [online]. Available at: http://www.dzs.hr/ [Accessed 15 April 2011].

De la Feria et al, 2009. Opting for opting in? Warwick economic research papers, Warwick: The University of Warwick [online]. Available at:

http://www2.warwick.ac.uk/fac/soc/economics/research/workingpapers /2010/twerp_927.pdf [Accessed 5 March 2011].

Ernst \& Young, 2009. Design and impact of the "Option to tax"System for Application of VAT to Financial Services. Available at: http://www.ey.com/Publication/vwLUAssets/EY_-

EBF_Report_on_O2T_system_for_application_of_VAT/\$FILE/Acrobat $\% 2$ ODocument.pdf [Accessed 5 November 2010].

European Commission, 2006. Consultation Paper on Modernising Value Added Tax obligations for financial services and insurances [online]. Available at:

http://ec.europa.eu/taxation_customs/resources/documents/common/ consultations/tax/modernising_VAT_en.pdf [Accessed 5 January 2011].

European Commission, 2007. Accompanying document to the Proposal for a Council Directive, COM/2007/747, Impact assessment [online]. Available at:

http://ec.europa.eu/taxation_customs/resources/documents/taxation/v at/how_vat_works/vat_insurance/sec\%282007\%291554_en.pdf [Accessed 5 January 2011].

European Commission, Taxation and Customs Union, 1996. Value Added Tax, A study of Methods of Taxing Financial and Insurance Service. Brussels [online]. Available at:

http://ec.europa.eu/taxation_customs/resources/documents/taxation/v at/key_documents/reports_published/methods_taxing.pdf [Accessed 7 March 2011].

International Factors Group, 2008. A study of Legal Environment across Europe. Brussels. [online]. Available at:

http://www.abfa.org.uk/members/newsletter/EU-LegislationReport.pdf [Accessed 5 February 2011].

Official Gazzette, 1995. Zakon o porezu na dodanu vrijednost. Zagreb: Narodne novine d.d., no. 47/95. 
Official Gazzette, 1996. Pravilnik o porezu na dodanu vrijednost. Zagreb: Narodne novine d.d., no. 60/96.

Official Gazzette, 2009. Zakon o izmjenama i dopunama Zakona o porezu na dodanu vrijednost. Zagreb: Narodne novine d.d., no.87/09.

Official Journal of the European Union, Council Directive 2006/112/EC on the common system of value added tax [online]. Available at: http://eur-

lex.europa.eu/LexUriServ/LexUriServ.do?uri=OJ:L:2006:347:0001:0118:e $\mathrm{n}:$ PDF [Accessed 5 November 2010].

PricewaterhouseCoopers, 2006. Study to Increase the Understanding of the Economic Effects of the VAT Exemption for Financial and Insurance Services [online]. Available at: http://ec.europa.eu/taxation_customs/resources/documents/common/ publications/studies/financial_services_study_managementsummary_e n.pdf [Accessed 5 November 2010].

Sixth Council Directive 77/388/EEC, 1977 on the harmonization of the laws of the Member States relating to turnover taxes - Common system of value added tax: uniform basis of assessment [online]. Available at: http://eur-

lex.europa.eu/LexUriServ/LexUriServ.do?uri=CELEX:31977L0388:EN:HTM L [Accessed 5 January 2011].

Šalata, D., 2011. Financijske usuge u sustavu poreza na dodanu vrijednost. Specialistic postgraduate work. Faculty of Economics and Business Zagreb.

Šimović, J. et al, 2006. Fiskalni sustav i fiskalna politika Europske unije. Zagreb. Pravni fakultet Sveučilišta u Zagrebu 